\title{
PASTORAL ÇOCUKLAR: SYLVIA PLATH VE NIILGÜN MARMARA
}

\section{Feryal ÇUBUKÇU ${ }^{1}$ Merve GÜVEN ${ }^{2}$}

\begin{abstract}
Öz: 20.yüzyılda kadın ile ilgili felsefe, sosyoloji, psikoloji gibi alanlarda yaşanan önemli gelişmeler edebiyat alanına yansımıştır. Amerikan edebiyatını okuyup, inceleyen Türk edebiyatçılar da, onlar ile etkileşim içinde olmuştur. Bu çalışmada Amerikalı şair Sylvia Plath (1932-1963) ve İngiliz Dili ve Edebiyatı bölümünü bitirme tezini Plath üzerine yapan Türk şair Nilgün Marmara'nın (1958-1987) yapıtlarında cinsiyet ve kimlik sorununun önemli bir yeri vardır. Bu çalışmanın amacı, Sylvia Plath ile Nilgün Marmara arasındaki ilişkiyi şiirleri ve yaşam öyküleri açısından değerlendirmektir. Bu bağlamda Plath'ın "Daddy" "Medusa", "Lady Lazarus" adlı şiirleri Marmara'nın ise; "Mezar", "Kan Atlası", "Kuşum ve Ben" adlı şiirleri sosyolojik ve psikoanalitik eleştiriden yararlanılarak çözümlenmiştir. Farklı kültürlerde yaşayan Marmara ve Plath'in arasında, kişilik özellikleri bakımından çok fazla farklılıklar bulunmadığ gibi, toplumsal cinsiyet ideolojisinin yarattığı ortak sorunlar ve yaşam öykülerinde benzerlikler de bulunmaktadır. İki şairin eserlerinde, kan, baba, aile ve yokluk gibi birçok ortak imge ve tema saptanmıştır. Hem Plath hem de Marmara'da anneye karşı olan sevginefret tutumu, suçluluk hissi, bastırılmış geriye atılan çocukluk duyguları, erkek kardeşe duyulan kıskançlık, ölen babanın idealleştirilmesi, annenin kızını idealleştirmesi, ruh ikizini araması, çatışan anne-kız ilişkisi, kafalarındaki kadın imajına bağlılık ve intihar, feminist eleştirinin "dişil estetik" önerisini doğrulamaktadır. Dolayısıyla, bu çalışma feminist yazına katkı sağlama ve kadın sorununun edebiyattaki yansımalarını ortaya koyma açısından önem taşımaktadır.
\end{abstract}

Anahtar Sözcükler: Feminizm, Sylvia Plath, Nilgün Marmara, Kimlik.

\section{Giriş}

Geçmişten günümüze değin toplumsal yapı ile edebiyat arasında sıkı bir ilişki ve etkileşim olmuştur. Edebiyat, ortaya koyduğu eserler yoluyla toplumsal yap1 içinde var olan kültürel ve ideolojik pratikleri yansıtmakta ve etkilemektedir. Modernizm ile birlikte toplumsal yapı sürekli bir değişim geçirmekte,

\footnotetext{
${ }^{1}$ Doç. Dr., Dokuz Eylül Üniversitesi, Buca Eğitim Fakültesi, Yabancı Diller Eğitimi Bölümü, İngiliz Dili Eğitimi Anabilim Dalı. feryal.cubukcu@deu.edu.tr

${ }^{2}$ Araş. Gör., Dokuz Eylül Üniversitesi, Buca Eğitim Fakültesi, Güzel Sanatlar Eğitimi Bölümü, Resim-İş Eğitimi Anabilim Dalı. merve.guven@deu.edu.tr
} 
durağanlığı dışlamakta ve çeşitliliği savunmaktadır. Modernleşme sürecinde bireyler sürekli değişen toplum yapısına ayak uydurmada zorlanırken, diğer yandan ilerlemeci değişim anlayışı ile kurulan ekonomik, sosyal ve kültürel düzen bireyin gelişmelere alışmasını zorunlu kılmaktadır. Buna bağlı olarak kadın ve erkek tanımlarında da değişimler yaşanmakta, toplumsal cinsiyet rollerine eklemeler ve çıkarmalar yapılmakta, bu durum da bireylerin tutumlarında farklılıkların oluşmasına neden olmaktadır.

Toplumsal cinsiyet içinde değişen roller ile birlikte özellikle 60'lı yıllardan sonra "kadın hakları" sık tartışılan kavramlardan olmaya başlamıştır. Kadın hakları kavramının içeriği ve talepleri ise feminist hareketin öncülüğünde ortaya koyulmuştur. Genel anlamda feminizmi kadın-erkek ayrımcılığına karşı çıkarak, cinsler arasında eşitliği savunan bir görüş olarak tanımlayabiliriz. Bununla birlikte kadın sorunu, yalnızca kadın erkek eşitsizliği olarak sınırlandırılamayan; ekonomik, politik, ideolojik, psikolojik ve kültürel boyutları iç içe geçmiş karmaşık bir olgu olarak karşımıza çıkmaktadır.

Tarihsel açıdan feminist hareket; I. Dünya Savaşı öncesi-1920 yılları arasında "ilk dalga", 1960-1970 y1lları arası "ikinci dalga" ve 1980-1990 y1lları arası "üçüncü dalga" olmak üzere üç döneme ayrılmaktadır (Özkişi, 2013, s. 892). 1960'l1 yıllarda başlayan "ikinci dalga" feminist hareket olarak anılan süreç özellikle 1986 sonrasında oldukça geniş bir kitleye yayılmıştır. Feminist bilincin yerleştiği bir kültürde doğan "üçüncü dalga " feminist hareket ya da "Fransiz feminizmi", "Derrida ve Foucault aracillğıyla Postmodernizm/Postyapısalc1lığa götürmüştür" (Beasley, 1999, s. 48'den aktaran Grant, 2006). Üçüncü dalga hareket; sahte teori, çok kültürlülük, siyahi feminist eleştiri, eşcinsel teori, Post-Marksist feminizm ve pozitif kadın kavramlarını ele almaktadır. Toplumsal yaşamdaki önemli değişimler sonucu şekil alan bu üç dönemde, temel olarak ataerkil düzen içinde kadınların konumunu sorgulanmış, ancak “...feminist görüşü bir bütün olarak çözümlemeye imkân tanıyan bir teori geliştirilemediğinden, feminist düşünürler, liberalizm, Marksizm, psikanaliz, varoluş̧̧uluk, radikalizm..." (İmamçer, 2002, s. 158) gibi düşünce akımlarını sentezlenen yeni teoriler ("Liberal Feminizim", "Marksist Feminizm”, “ Radikal Feminizm”, "Feminizm ve Varoluşçuluk", "Psikanaliz ve Feminizm", "Post-Marksist Feminizm") ile kadın sorununa çözüm aradılar. Feminist kuramcıların gerek toplumsal yaşam içinde gerekse edebiyat incelemeleri alanında ortaya koyduğu bu teorilerdeki ortak nitelik ise ataerkil düzende kadının sömürülmesine karşı duran tutumdur.

Bununla birlikte feminist edebiyat eleştirisi “...1960'larda Amerika'da, İngiltere'de, Fransa'da toplumsal ve siyasal bir savaşım olarak canlanan genel feminist hareketin edebiyat alnına kaydırılması sonucu ortaya çıktı" (Moran, 2013, s. 249). Moran, feminist eleştiriyi öncelikle edebiyata kadın okurlar açısından yaklaştığı için "okur merkezli kuramlar" (duygusal etki kuramı, alımlama estetiği ya da kuramı) kapsamında değerlendirirken, feminist eleştirmenlerin iki ana yaklaşımları olduğunu ifade etmiştir. Bunlar; okur olarak kadına yönelik eleştiri ve yazar olarak kadına yönelik eleştiridir (Moran, 2013, 
s. 250). Okur olarak kadına yönelik feminist eleştiri "Kişi kadın doğmaz, kadın olur / kadın doğulmaz, kadın olunur" (Gamble, 2000'den akt. Grant, 2006, s. 12) söyleminden yola çıkmaktadır. Modern feminizmin en önemli savuncusu Simone de Beauvoir'a göre kadın olmak biyolojik ya da psikolojik bir durum olmaktan ziyade eril ideolojinin şekillendirdiği dişil davranış kodlarının bütünüdür. Beauvoir'ın kuramınından yola çıkan Germaine Greer, erkek arzularının nesnesi olmak üzere inşa edilen kadın bedeni algısında her şeyin başka türlü olabileceğini öne sürmektedir.

Diğer yandan yazar olarak kadına yönelik feminist eleştiri ise, önemli kadın yazarların edebiyat tarihinde yeterince yer almaması sorununu ele almaktadır. Kadınların unutulmuş geçmişini geri kazanmaya yönelik bu bakış açısı 18. ve 19. yüzyılların kadın yazarları tarafından kaleme alınmış ancak ilk baskıdan sonra unutulmaya yüz tutmuş bir dizi romanın yeniden basılmasına yönelik çalışmalara önayak olmuştur. Dale Spender'in Romanın Anneleri: Jane Austen'dan Önce 100 İyi Kadın Romancı (1986) adlı çalışması ile Elaine Showalter tarafindan kaleme alınan Kendilerine Ait Bir Edebiyat: Bronte'den Lessing'e İngiliz Kadın Romancılar (1977) adlı eseri buna örnek olarak gösterilebilir. Kate Millet ise sosyal yaşamda kadın ezilişinin erkek romanlarına yansıdığını ve erkek romanlarında yaratılan klişe kadın tiplerinin kadın sömürüsünü pekiştirdiğini ifade eder. Erkek romanlarının bu niteliği, erkek egemen dünyadaki kadın rolünü kontrol altında tutmayı hedefleyen politik bir uygulamadir (1987, s. 45). Bu nedenle ikinci dalga Anglo-Amerikan feminizm kuşağının önemli teorisyenlerinden Kate Millet, Elaine Showalter, Sandra Gilbert Susan Gubar ve Ellen Moers ortaya koyduğu Jino-eleştiri kavramının amacı kadın edebiyatı geleneğinin ilkelerini ya da evrimini izlemektir. Kadınlar toplumsal hayatta karşılaştıkları baskılar nedeniyle dünyayı ve yaşamı erkeklerden farklı algılar bu farklı1ık onların zekâları ya da yetenekleriyle ilgili bir durum değil politik ve kültürel bir olgudur. Kadınların toplum içinde uğradıkları haksızlıklar onların bir alt-kültür yaratmasına neden olurken; üstkültür olan edebiyat alanındaki yaratılarına seçtikleri konular, sergiledikleri davranışlar, savundukları değerler bağlamında etki eder (Showalter'dan, 1977, s. 11, akt. Moran, 2013, s. 255). Dolayısıyla kadın eserleri arasında "dişil imge", "dişil dil" ya da en azından benzerlik vardır.

Bu çalışmada ele alınan iki kadın şair; Sylvia Plath ve Nilgün Marmara, arasında feminist edebiyat eleştirisi kuramı bağlamında bir değerlendirme yapılmıştır. Sylvia Plath ilk Amerikan feminist roman olan Sırça Fanus adlı eserin yazarıdır. Plath hayranı olan Nilgün Marmara Sylvia Plath'in Şairliğinin Intiharı Bağlamında Analizi adlı inceleme çalışmasında Sırça Fanus eserini "giz dökümcü türün uç noktasında bir otobiyografik roman" (2007, s. 41) olarak tanımlamaktadır. Marmara ve Plath'in genç yaşta intihar ederek ölmesi gibi benzerlik gösteren biyografik özellikleri, eserlerindeki öz biçim ilişkisi, konu ve tema seçimleri, imge örüntüsü, şiirlerine yansıyan psiko-sosyal özellikleri arasında karşılaştırma yapılmıştır. 


\section{Sylvia Plath}

27 Ekim 1932 de Boston'da doğan Sylvia Plath, Avusturya'lı bir anne ile Alman bir babanın ilk çocuğuydu. Boston Üniversitesi biyoloji bölümünde profesör olan Otto Plath, bal arıları üzerinde kitaplarıyla tanınan ünlü bir bilim adamıydı. Kendisinden yirmi üç yaş küçük olan master öğrencisiyle evlenmiş, henüz kızı Sylvia sekiz yaşına gelmeden on gün önce, tedavi edilemeyen şeker hastalığına bağlı ayağının kesilmesi sonucu ortaya çıkan komplikasyon sebebiyle vefat etmişti.

Sylvia Plath yıllar sonra annesinin ilgisini hastalıklı olan erkek kardeşine daha çok vermesi sebebiyle yalnız geçirdiği çocukluktan bahseder. Galli Poet Dylan Thomas'1 göremediği gerekçesiyle önce bacağında jiletle deneme yapmış, sonra da Harward üniversitesine kabul edilmediği için 1953 Ağustosunda annesinin uyku haplarını alarak ilk intiharına kalkmıştı. Freud (1910) kadın şairlerin ruhsal baskıyı daha çok hissettiklerini ve bilinçaltındakileri sesli dile getirecek kadar cesur olduklarını, bu yüzden intihara meyilli olduğunu söyler. Plath'in, eşinden ayrıldıktan sonra gelen 2.intiharı ise başarılı olacak, gaz ocağını sonuna kadar açarak, pencereyi ve kapıyı kapatarak ölüme gidecektir.

Plath'ın şiirlerinde bu bireysel, kişisel ve kadın kimliği sorunlarıyla boğuştuğunu okuyucu hemen fark eder. Gerish (1996-1998, s. 737) intihar olgusunu incelerken, intihara kalkışan veya edeni 3 çerçevede inceler: kültürel, aile içi dinamikleri (özellikle anne-kız), ve ruhsal tepkileri (ruhsal süreç). Plath, burada intihar edenlerin ortak özelliklerinin hepsine sahiptir. Ruhsal süreç bağlamında aşağıdaki unsurlar ön plandadır:

a. anneye karşı olan sevgi-nefret tutumu,

b. suçluluk hissi,

c. bastırılmış geriye atılan çocukluk duyguları,

d. erkek kardeşe duyulan kıskançlık,

e. ölen babanın idealleştirilmesi,

f. annenin kızını idealleştirmesi,

g. ruh ikizini araması,

h. çatışan anne-kız ilişkisi,

i. kafasındaki kadın imajına bağl1lık ve

j. intiharı, kendi sahte kişiliğini yok eden bir unsur olarak görme.

Ölümünden 4 ve 8 gün önce yazdığı son şiirleri olan "baba " ve "Medusa", Sylvia Plath'ın anne ve babasıyla olan sorunlu ilişkisini yansıtmaktadır. Babasını Nazi, kendisini ise Yahudi'ye benzeterek, Dachau, Auschwitz ve Belsen katliamlarını göndermelerde bulunarak, "chuffing," "achoo,", "gobbledygoo" gibi çocuk nidaları kullanıp, kendi çocuk ruhundaki savaşı durdurmaya çalışır. Daha ilk mısralarda, kendisini siyah bir ayakkabı içindeki ayağa benzetip, nefes alamadığını ve bu işin bitmesi gerektiğini belirtir. 8 dize de mermer kelimesi mezar taşını çağrıştırmakta ve God-Tanrı kelimesi kullanılmaktadır. 9. mısrada ürkütücü bir heykel vardır, ama bu tüm ABD'yi kaplamaktadır. 14. dizedeki "recover" kelimesinin pek çok anlamı vardır, 
hastalığ 1 yenmek, iyileştirmek ve tekrar kazanmak ve Plath, artık Almanca bir kelime ile babasına hitap etmektedir. Kendi diline ve ruhuna yabancılaşma burada barizdir. Bunun acı mı yoksa kızgın bir iç çekme olup olmadığı sonraki satırlarda belli olacaktır. 18.dizede savaş kelimesi 3 defa kullanılmıștır ve hamurun üzerinden adeta bir buldozer geçmiştir, kendisinin hayatta mücadelesini üzerinden buldozer geçmiş bir savaşa benzetmektedir, Plath.

I was ten when they buried you. Seni gömdüklerinde 10 yaşındaydım At twenty I tried to die. 20 sinde ölmeye çalıştım And get back, back, back to you. Sana dönmek istedim/kavuşmak I thought even the bones would do. Kemikler bunu yapar diye düşündüm.

Bir sonraki dizeler ise Plath'1 "I do I do", evlilik yemini ettiğini söyler. Plath, babasına benzeyen biriyle evlenmiştir. Sonraki mısralarında ise 7 yıllık esaretin bittiğini vurgular, okuyucu o zaman bu baba şiiri mi yoksa ayrıldığ eşi Ted Hughes'a bir gönderme olup olmadığını düşünmeye başlar. Bu kişi, 7 yıl boyunca onun kanını emmiştir. Son satır ise "artık bitirdim" cümlesidir, şiir bitmiştir, ama babasını da eşini de öldürmüştür.

"Baba" şiirinden 4 gün sonra ise "Medusa" yazılır. Bu şiir annesine olan duygularını yansıtmaktadır, içi gene kırık ve eziktir. Yunan mitolojisine gönderimlerde bulunan Plath, annesinin adı olan Aurelia yerine onun Yunanca karşıllı̆ı olan Medusa'yı kullanmıştır. Aurelia aulita, bu aynı zamanda bir çeşit denizanasıdır. Annesinden uzaklaşmak istemektedir. Kırmızı plesanta ile aralarındaki yakın kan bağını hatırlamakta, hem annesine yakın olmak hem de bağımsızlığını kazanmak duyguları arasında gelip gitmektedir. Şiir boyunca, Medusa, vücut organları ile anlatılmaktadır: mouth, eyes, ears, head, umbilicus, placenta/ağız, gözler, baş, kordon bağı, plasenta. Atlantik kablosu olnasına rağmen aralarında, şair Medusa'dan yani annesinden kaçamamaktadır. Ortak şair arkadaşları Assia Wevill ile eşinin ihanetini yakaladığında annesi de evdedir ve bu Sylvia Plath'ın öfkesini artırmıştır. Kendisinden daha ünlü bir şair olan eşi Ted Hughes, Plath'in ölümünden sonra Assia ile evlenecektir. Assia'nin sonu da Sylvia ile aynıdır, ama tek farkla: gaz ocağını açtı̆̆ında yanında kızı da vardır. Sylvia Plath annesine düşkündür, hatta 9 yaşındayken annesine asla evlenmeyeceğine dair yemin bile ettirir. Annesinin bu kadar kendilerine bağlı olmasından aşırı derecede hoşnutsuzdur. Erkek kardeşine yazdığ mektupta, annemizin yaşantısını 20 yıl kadar emdikten sonra, ona mutluluk parçaları getirmek bizim görevimiz diye yazar (Plath, 1992). Plath'ın annesiyle olan bu çarpık ilişkisi ve duyguları, aslında kendisine yönelik duyguları ile eş değerdir. Aslında başarılı bir baba, anne ve eş arasında kendisini boğulmuş hissetmekte, anlaşılamadığından dolayı ve kendisinden beklediği görevlerin artarak ona baskı yapmasından dolayı, hayata karşı savaş benzetimleri kullanarak, kendini de ezilmiş ve yıkılmış olarak görmekte ve kaçış yolu bulamamaktadır.

Uzun süre yazıştığı bir arkadaşı onu gördüğünde "Aman Tanrım, hiç spontane bir hareketi yok, baştan sona maske takıyor" diye şaşkınlığını dile getirmişti, eşi 
de "son 3 ay dışında sanki onun gerçek halini hiç görmedim" demekten kendini alıkoyamamıştı (Alexander, 1991, s. 60). Taktığı ve kendisini sakladığı psikolojik ve sanatsal maskeler o kadar fazlaydı ki, artık öfkesini ve hoșnutsuzluğunu kendisine yöneltmiști. "The Bee Meeting” şiirinin bașında, "kolsuz yazlık elbisem içinde kendimi çok incinir görüyorum, hiç bir korumam yok. Birisi beni sever mi?” diyerek kendi kendine kırılganlı̆̆ını göstermiştir. Plath'1n bu durumu bazı yazar ve doktorlar tarafindan şizofreni olarak tanımlanmıştır (Lant, 2001). Lady Lazarus onun bu ikilemini vurgulamakta, şair, sonra da "sizi korkutuyor muyum?" diye sormaktadır. Şiir "gene yaptım" (I have done it again) ile başlamaktadır, her 10 yılda bir Plath'ın yaptığı şey intihardır. Kendisini bir Yahudi'ye benzeterek, karşısındakinden yüzündeki peçeteyi alıp çekmesini ister, sonra da "size korkutuyor muyum?" diye merak eder. Tıpkı dokuz canlı bir kedi gibidir, ama her intiharından sonra fistık yiyen kalabalık ona bakmaya gelmiştir. Ölüm bir sanattır ve kendisi bunu çok iyi yapmaktadır. Travmatik olan ölüm değil, tekrardan dünyaya dönmek, dirilmektir. Karşısındakine "Herr Dockter" ve "Herr Enemy,"diye seslenir, Herr God, Herr Lucifer'e kendisinden sakınmasın1, zira küllerinden yeniden doğacağını söyler. Feminist bakış açısıyla, ataerkil toplumdaki kadın sanatçının otonomi/bağımsızlık için didinmesi, hem onun karanlık ve depresif duygularını ortaya çıkartır hem de ölüm ile bunun bitmeyeceğini ve kendisinin yaratıcı yeteneklerinin ölümle bile sona ermeyeceğini vurgular. Karşısındaki bir erkektir, ama Plath onu Nazi doktoru, şeytan ve tanrı ile özdeşleştirmekte, içinde bulunduğu ataerkil toplumun kendi üzerindeki etkisini vahşi, yıkıcı ve depresif olarak betimlemektedir. O yüzden son satırda söylediği "Küllerimden, kızıl saçlarımla yeniden doğuyor ve erkekleri yutuyorum" tehdidine kimse inanmaz. Kızıl saçları kendisinin kızgınlığını ve dünyaya olan öfkesini gösterir, fakat okuyucu şairin ne kadar güçsüz ve incinir olduğunu anlamıştır.

\section{Nilgün Marmara}

Nilgün Marmara, Balkan göçmeni olan bir ailenin iki kızından biri olarak, 13 Şubat 1958'de İstanbul, Moda'da dünyaya geldi. Karl Marx'1n görüşlerini benimsemiş bir solcu olan babası Fikri Marmara, muhasebe müdürüydü. Babası Bulgaristan'ın Plevne şehrinden, annesi ise çocukluk ve gençlik yıllarına dair büyük bir özlem duyduğu Vidin şehrinden İstanbul'a göç etmişti.

Öğrenim hayatında başarılı bir öğrenci olan Nilgün Marmara, ilkokul beşinci sınıfta kolunu kırmasına rağmen tüm kolejlere giriş hakkı kazandı (solaktı, sol kolunu kırmıştı). Marmara'nın iyi bir eğitim almasını isteyen ailesi onu önce Avusturya Lisesi'ne kayıt ettirdi fakat daha sonra maddi nedenlerle kaydını Kadıköy Maarif Kolejine aldı. Liseyi bitirene kadar bu okulda okuyan Marmara, üniversite eğitimine İstanbul Üniversitesi Türk Dili ve Edebiyatı bölümünde başladı. Ancak o dönemde İstanbul Üniversitedeki öğrenci profilinin hâkim olduğu sağ görüş, özellikle babasının etkisiyle Marmara’nın sempati duyduğu sol görüş ile örtüşmemekteydi. Bununla birlikte Marmara hayatının hiçbir döneminde aktif bir siyasi hareketin savunucusu olmamıştır. Üniversitedeki siyasal ve sosyal ortamından rahatsızlık duyan Marmara, ertesi yıl tekrar sinava 
girerek Boğaziçi Üniversitesi İngiliz Dili ve Edebiyatı bölümüne başladı. Burada, üniversite öğreniminin yanında yaşamı boyunca etkisi altında kaldığı Sylvia Plath üzerine incelemeler yapmaya başladı.

Bu dönemde Türkiye'de yaşanan 1980 askeri darbesi Nilgün Marmara'nın edebiyat ile ilişkisine yeni bir boyut kazandırdı. Siyasal olaylar nedeniyle edebiyat çevresi genellikle ev partilerinde toplanıyor, edebiyatla ilgili uzun sohbetler yapillyordu. Bu sohbetler sırasında Nilgün Marmara, ünlü şair ve yazarlardan; İlhan Berk, Fazıl Hüsnü Dağlarca, Cihat Burak, Turgut Uyar, Edip Cansever, Cemal Süreya ve genç kuşaktan; Seyhan Erözçelik, Orhan Alkaya, Lale Müldür, Günseli İnal, Cezmi Ersöz, Turgay Özen, Mustafa Irgat gibi isimlerle dostluk kurdu. Ev partilerinin birinde tanıştığ 1 Kaan Önal ile birlikte yaşamaya başladı. Evliliğe karşı olan Nilgün Marmara hem kendisinin hem de Kaan Önal'ın ailesinin 1srarı nedeniyle 1982 y1lında evlendi. Bir süre sonra (1985) Sylvia Plath 'in Şairliğinin Intihar Bağlamında Analizi adlı lisans tezi ile lisans eğitimini tamamladı. Mezun olduktan sonra iş hayatına atıldı. Marmaris'te bir tatil köyünde çalıştı. Farklı şirketlerde yönetici sekreterliği, metin yazarlı̆̆ gibi işler yaptı. Bebek'te Mısır Konsolosluğu'nda çalıştı. Ancak Nilgün Marmara'nın tüm bu iş deneyimleri kısa sürdü ve yaşamının geri kalanında sadece şiir yazd.

Yalnızca yakın arkadaş çevresi ile paylaştığı şiirler Daktiloya Çekilmiş Şiirler (1988) Metinler (1990 ve Kırmızı Kahverengi Defter (1993) adlı günlüğünden yapılan derleme ölümünden sonra kitaplaştırıldı. Nilgün Marmara'nın şiirleri özellikle konu anlamında varoluşçuluk akımından etkilenmiştir. Varoluşçu edebiyat metinlerinde sıkça rastlanan; kendilik (ipseite), içe dalış, iç neden, hiçlemek gibi özellikler Marmara'nın şiirlerinde açıkça izlenebilir. Ayrıca varoluşçu edebi metinlerinde karşılaştı̆ıımız sıkıntı, yalnızlık, bunalım, umutumutsuzluk, yabancılaşma, rastlantı, iletişimsizlik, intihar gibi konuları işler. Ancak Marmara'nın özgün anlatımını varoluşçu bir edebiyat olarak tanımlamak ve bu konuları seçmesindeki nedeni yalnızca varoluşçuluk ilgisi ile sınırlandırmak eksik bir değerlendirme olacaktır. Marmara'nın seçtiği konuların temelinde onun manik depresif hastalığının ve toplumsal yaşamda kadın olarak karşılaştığı zorlukların etkisi yadsınamaz. Nitekim 13 Ekim 1987'de, henüz 29 yaşındayken "yaşama karşı ölüm diyerek" evinin beşinci katından atlayarak yaşamına son vermesi, geride bıraktığı günlüğü ve yaşamını yansıtan şiirleri bu etkileri ortaya koyar.

Nilgün Marmara'nın şiirini daha iyi anlayabilmek için onun psiko-sosyal özelliklerine değinmemiz gerekiyor. Yaygın bir ruh sağlığı sorunu olan depresyon ve bağlı olarak intihar davranışını açıklayan birçok kuramsal yaklaşımdan birisi de Beck'in bilişsel modelidir (Beck, 1963). Bu modele göre depresyona yatkın bireylerde, kendisine, dış dünyaya ve geleceğe karşı olumsuz beklentiler vardır. $\mathrm{Bu}$ tutumlar ve kavramlar kişinin düşüncesinde sistematik hatalara, olumsuz yargılara ve sessiz kabullenişlere neden olur (Beck, 1979). İntihar düşüncesinin yoğunluğu ve şiddeti ise geleceğe yönelik umutsuzluk derecesi ile doğrudan ilişkilidir. Bu bağlamda toplumsal kurumlar ve erkek 
egemen edebiyat dünyası Nilgün Marmara'nın depresyona yatkın kişiliğini etkileyen önemli faktörlerden olabilir. Örneğin, toplumsal ve ailevi baskılar nedeniyle kendini bir anda karşı durduğu evlilik kurumunun içinde bulmuştur. $\mathrm{Bu}$ evlilik nedeniyle Nilgün Marmara, Kaan Önal ile birlikte on altı aylı̆̆ına Libya'ya yerleşecek ve buradaki baskı ortamı içinde hayatının en sıkıntılı dönemlerini geçirecektir. Marmara Libya'daki günlerinde yaşadığı yabancılaşmayı şu sözlerle ifade eder; "Bir tarafı Gadard şantiyesi, bir taraf Altmann gölü bu garip mekânın ortasındaki ben Nilgün.” (Kırmızı Kahverengi Defter, 21).

Bununla birlikte evliliği ve eşiyle ilişkisi Marmara'yı yalnızlaştıran etmenlerden biri olarak karşımıza çıkar. Marmara'nın günlüğünde eşi ile ilgili "Kağan eteğine pis bir herif oldu, her gün barlarda sürtüyor. Soruyorum "yine hangi bardaydın bugün?" "Ambar'da" diye yanıtlıyor. (Ekipmanı kontrol ediyor ambarda) (21). Özellikle Libya'da geçirdiği günlerde eşi dahil olmak üzere paylaşımda bulunabileceği kimse yoktur yanında. Kuşum ve Ben adlı şiirinde bu durumun yansımalarını gözlemleyebiliriz. İlk iki dizede kuşum diye nitelendirdiği eşi ile kendisini bir aynaya sıkışmış ya da kafese kapatılmış olarak yansıtır. Dördüncü dizede ise yaşadığı ortamı nasıl algıladığını soğuk kar metaforu ile ifade eder. Altıncı dizeye gelindiğinde eşi ile arasındaki tek bağ olarak gördügü cinsellikten bahseder. Sekiz ve dokuzuncu dizelerde ise bu bağ çözülürse geriye hiçbir şey kalmayacağını ifade eder. Bu şiirin birinci ve dokuzuncu satırlarındaki ayna imgesi ise göstergebilimsel açıdan oldukça önemlidir:

“.... ama ayna kişiliğinden ödün vermez; kendimize aynaya bakarak bakarız. Ayna ürkünçtür; çünkü yalan söyleyemez. Görüntüye mutlak sadakat, edilginliğin en uç noktaya vardığı yerle örtüşür aynada; kişilik, bütünüyle ters yönden ele geçirilmiştir burada; kusursuz bağımlılık, kusursuz kararlılığın göstergesidir esasen" (Ergüven, 42).

Aynanın neyi göstereceği algıya bağlıdır; gelgelelim, algı gerçekten tamamen bağımsız bir kavram değildir. Marmara'nın evliliğini bu şekilde yansıtması ve ayna imgesini kullanması onun şair ve kadın duyarlılığının yanı sıra birtakım gerçeklere dayanır.

Salt evliliği değil mesleki yaşantısı da yalnızlık ile çevrilidir. Nilgün Marmara erkek egemen edebiyat dünyası içinde kendine bir yer edinememiştir. Kullandığı dişil imgeler birçoğu arkadaş çevresinden olan erkek şairler tarafindan yeterince anlaşılmamış, hatta kimi zaman okunmaya değer bulunmamıştı.

26 Nisan Pazar Gecesi anne baba evindeki televizyonda gördüğüm yeşil ışınla ve babamın "bu ülkede gerçek deli bile yoktur, hepsi sahtekârdır" demesiyle başladı. 25 Nisan Cumartesi gecesiyse E... derin korkusu ve suçluluğuyla bana saldırdığında aldığım derin yara, 26 Nisan Pazar günü ben tarafından düşünüldü ve her şey bir bir açıklığa kavuştu. Ben bir tehdidim onlar için çünkü bir varlığım, cinssiz bir bebek rolünü bulamamış, iyi ezberleyemediğimiz bir hayvan, her yöne savrulabilir, dağılabilir bir atom... Bu atomik kuvvetten 
korkuyorlar, enerjisinden, çekirdek enerjiden, çünkü onlar potansiyeli ekonomik... (Marmara, 1993, s. 102).

Marmara'nın günlüğünde ifade ettiği gibi toplumsal cinsiyet rolü olan "kadınlık" daima şairliğinin önüne geçiyordu. Ondan beklenen eş olma, anne olma, kız evlat olma rollerini reddettiğinden çevresi tarafından "cinssiz bir bebek, rolünü bulamamış..." olarak nitelendirildiğini düşünüyordu. Marmara'nın Mezar adlı şiirinde bu durumun yarattığı çıkmaz açıķa görülebilir:

"tükenirdi monolog/

kaçarken içine düştüğüm kara toplum"

Nilgün Marmara, içinde süregelen çatışmanın toplumsal sorunlarla birlikte çözümsüz bir sona gittiğini ifade eder. $\mathrm{Bu}$ umutsuz ruh hali onu intihara sürükleyen yegâne unsurlardan biri olarak karşımıza çıkar. Ölümünden bir yıl önce yazdığı Kan Atlası (1986) şiirine "Ben babamın yuvarladığı/çığın altında kaldım" diye başlar. Şiir boyunca toplumsal sorunların kadın- birey üzerinde yarattığı etkilerin nasıl şiddete dönüştüğünü gözlemleyebiliriz. Kadına yönelik bu sembolik şiddeti Marmara, bir yandan "boy atmışta salgıları cücelmiş̧ sezgileri" diye eleştirirken diğer yandan "Ey yüzleri bir babakuş gölgesinde çakılmış olanlar üzgün adım ileri marş!” diyerek otoriteye karşı suskun bir tutum içine girmiştir.

\section{Sonuç}

Paralel sıra dışı yaşamlara sahip olarak adlandırılan, kadın olmanın çelişkili süreçlerini benliklerinde duyarlı olarak yaşayan, Plath ve Marmara, kadınları hapseden, boğan toplumsal sırça fanustan intihar ile kurtulmaya çalışmışlardır. (Soyşekerci, 2012). Genel anlamda kişinin isteyerek yaşamına son vermesi olarak tanımlayabileceğimiz intihar olgusu, Sylvia Plath ve Nilgün Marmara'yı anlama açısından kilit bir role sahiptir. İntihar davranışı; intihar düşüncesi, intihar girişimi ve tamamlanmış intihar olmak üzere üç grupta ele alınır (Sayıl, 2000). Bu açıdan değerlendirdiğinde Marmara ve Plath varoluşu sorgulayan yaşam felsefesinin yansıması olan şiirlerinde, intihar düşüncesi üzerinde yoğunlaşır. Plath yakın çevresi tarafından intihar eğilimli bir genç kız olarak tanımlanıp, yineleyici intihar girişimlerinde bulunurken; intiharı şaşkınlık ve kuşkuyla karşılanan Marmara, daha önce intihar girişiminde bulunmamıştır.

Bununla birlikte yaşamını tamamlanmış intihar davranışı ile sonlandıran Sylvia Plath ve Nilgün Marmara arasındaki ilişkiyi incelerken öncelikle onları intihar olgusuna yakınlaştıran nedenleri değerlendirmek gerekir. İntihar olgusunun nedenlerini temel olarak üç başlıkta inceleyebiliriz; kültürel yapı, aile içi dinamikler (anne-kız ilişkisi), ve ruhsal tepkiler (ruhsal süreç) (Gerish, 1996, 1998, s. 737). Kültürel yapı ile ilgili nedenlere baktığımızda yaşamını ABD ve İngiltere'de geçiren Plath'te intiharın sosyal tetikleyici yönü belli bir ölçüde bulunurken; Marmara'nın intiharındaki en önemli nedenlerden biri Türkiye'nin sosyo-kültürel yapısıdır. Bununla birlikte konuyu aile içi dinamikler açısından değerlendirdiğimizde “Annem bir catechist!” diyen Marmara'da özellikle 
toplumsal temelli aile baskıları dikkatimizi çekerken; Plath'in aile ilişkisinde birden fazla travmaya rastlarız. Plath'in Sırça Köşk adlı çalışmasının psikanalitik yorumlarına baktığımızda; Freud'un “ölüm itkisiyle” Lacan'ın "Odipus karmaşası" içinde bulunan ana karakterin, ölüm olgusuna arkaik bütünlüğe dönme çabası olarak yaklaştığını görmekteyiz. Plath'in intiharında bu “ana rahmine geri dönme”, acılardan kurtulmak için üretilen bir çözüm olarak karşımıza çıkmaktadır. Masterson (1988), anne ile çocuk arasındaki ilişkinin taşıdığı patolojik özellikler, çocuğun bağımsız bir benlik olarak gelişmesini engellediğini, gerçek benliğin yerini yazarın "sahte benlik" olarak adlandırdı̆̆ı hastalıklı bir oluşum alacağını belirtir (psikanalitik edebiyat). Plath'in anneye karşı olan beslediği nefret-sevgi çatışmasının yanında, babasına karşı beslediği büyük hayranlık da bulunmaktır. Babasına oldukça benzeyen eşi ile ilişkisi Plath'in ilerleyen dönemlerdeki ailevi yaşantısında yeni sorunlara neden olmuştur. Masterson'1n üzerinde durduğu sahte benlik, özellikle ölümüne yakın eşine karşı takındığı tavır olarak karşımıza çıkar. Plath intiharı, sahte benlikten kurtulmanın bir yolu olarak görmektedir. Nilgün Marmara da evliliğinde bir takım sorunlar yaşamaktadır. İntihar girişimlerinde risk faktörlerine baktığımızda; kadın olmak, yakın zamanda gerçek ya da sembolik anlam taşıyan kayıplar, yakın çevre ile iletişim sorunları yaşamak, başta depresyon olmak üzere bir ruhsal sorunun bulunması (Isometsa,1998 ve Tejedor, 1999) gibi nedenlere rastlarız. Marmara ve Plath'in yaşamında bu özelliklerin yanında şair olmalarından kaynaklanan duygusal yoğunluk etmeni bulunur. Her iki şair de yaşamları boyunca manik depresif özellikler gösterir. Bununla birlikte Plath'in intiharında ailevi travmalardan kaynaklı psikolojik etmenler baskın rol üstlenirken, Marmara'nın intiharında sosyal baskılardan ve iletişimsizlikten kaynaklı etmenler dikkat çekicidir. Marmara ve Plath'in biyografik özelliklerinin bir yansıması olarak, eserlerindeki öz biçim ilişkisi, konu ve tema seçimleri ve imge örüntüsü arasında benzerlikler bulunmaktadır.

\section{KAYNAKÇA}

Alexander, P. (1991). A Biography of Sylvia Plath. New York: Viking Press.

Beck A.T. (1979). Cognitive therapy of depression A treatment Manuel. New York: Guilford Press.

Christodoulides, N. (2005). Out of the Cradle Endlessly Rocking. New York: Rodopi.

Ergüven, M. (2007). Sırdaş Görüntüler. İstanbul: Agora Yayınevi.

Gerish, B. (1998). This is not Death, it is Something Safer. Death Studies, 22, 735-761.

Grant, M. J. (2006). A Feminist Analysis of Francis Poulenc's Sonata for Oboe and Piano. (Doktora Tezi). Ohio: The Graduate School of the University of Cincinnati.

Isometsa E.T. (1998). Lönnqvist JK. Suicide Attempts Preceding Completed Suicide. British Journal of Psychiatry, 173, 531-535. 
Lant, M. (1993). The big strip tease. Contemporary Literature, XXXIV (4), 620-669.

Masterson, J. (1988). The Search for the Real Self. New York: The Free Press.

Marmara, N. (2007). Sylvia Plath’in Şairliğinin Intiharı Bağlamında Analizi. İstanbul: Everest Yayınlar1.

Marmara, N. (2010). Daktiloya Çekilmiş Şiirler. İstanbul: Everest Yayınları.

Millet, K. (1987). Cinsel Politika. (Çev. Seçkin Sevi). İstanbul: Payel Yayınevi.

Moran, B. (2013). Edebiyat Kuramları ve Eleştiri. İstanbul : İletişim Yayınları.

İnal, G. (1994). Kırmızı Kahverengi Defter. İstanbul: Telos Yayınlar1.

Özkişi, Z. G. (2013). Müzik Disiplini Bağlaminda Feminist Müzik Teorisi ve Cinsiyet Semantiği. International Periodical For The Languages, Literature and History of Turkish or Turkic, 8 (12), 889-961.

Plath, S. (1992). Letters Home. Correspondence 1950-1963. Aurelia Schober Plath (Ed.). New York: Harper Perennial, Henceforth LH.

Sayı1. I. (2000). İntihar Davranış1, Kriz ve Krize Müdahale. Ankara: $A \ddot{U}$ Psikiyatrik Kriz Uygulama ve Araştırma Merkezi Yayınları, 6.

Soyşekerci, H. (2012). Hayaller ve Harfler: Sylvia Plath ve Nilgün Marmara'nın Ruh Ortaklığı. Feminist $F$ Dergisi, 2. Erişim tarihi: 24 Nisan 2014 http://www.cafrande.org/?p=45150.

Tresca, D. Maternal Ambition and the Quiet Righteous Malice of Motherhood: An Examination of Sylvia Plath's "Medusa". Musemedusa. Erişim tarihi: 10 Mart 2014, http://musemedusa.com/dossier_1/tresca/.

\section{PASTORAL CHILDREN: SYLVIA PLATH AND NILGUN MARMARA}

Abstract: The philosophical, sociological and psychological developments of the 20th century regarding women have found their reverberations in literature. Turkish novelists, dramatists and poets have been in close touch with their western counterparts. This study tackles and problematizes gender and identity issues in the poems of Sylvia Plath (1932-1963) and Nilgün Marmara (1958-1987) who wrote her thesis on Sylvia Plath. The poems "Daddy" "Medusa", "Lady Lazarus" by Plath and "Mezar", "Kan Atlası", "Kuşum ve Ben" by Marmara have been sociologically and psychoanalytically grappled in this study. Marmara and Plath who do not show many discrepancies in terms of personality, also share many common similarities on the basis of identity and gender issues despite the fact they came from different geographical locations. Both poets were interested in the same themes and motifs such as blood, father, family, alienation and loss. Both Plath and Marmara's hatred -love relationship with their mothers, sense of guilt, repressed childhood memories, jealousy of their brother, death of the father, being idealized by their mothers, seeking for a soulmate, woman's image, mother-daughter in conflict and suicidal attempts justify the female aesthetic of feminist 
criticism, that is why such a study is exemplary to show the gender issues and their reflections in literature.

Keywords: Feminism, Sylvia Plath, Nilgün Marmara, Identity. 